\title{
Spalling behavior and residual resistance of fibre reinforced Ultra- High performance concrete after exposure to high temperatures
}

\author{
Ming-Xiang Xiong必, J.Y. Richard Liew \\ Department of Civil Engineering, National University of Singapore, (Singapore) \\ $\triangle$ ceexm@nus.edu.sg
}

Received 17 January 2015

Accepted 7 May 2015

Available on line 10 N ovember 2015

\begin{abstract}
Experimental results of spalling and residual mechanical properties of ultra-high performance concrete after exposure to high temperatures are presented in this paper. The compressive strength of the ultrahigh performance concrete ranged from $160 \mathrm{MPa} 185 \mathrm{MPa}$. This study aimed to discover the effective way to prevent spalling for the ultra-high performance concrete and gauge its mechanical properties after it was subjected to fire. The effects of fiber type, fiber dosage, heating rate and curing condition were investigated. Test results showed that the compressive strength and elastic modulus of the ultra-high performance concrete declined slower than those of normal strength concrete after elevated temperatures. Polypropylene fiber rather than steel fiber was found effective to prevent spalling but affected workability. The effective fiber type and dosage were recommended to prevent spalling and ensure sufficient workability for casting and pumping of the ultra-high performance concrete.
\end{abstract}

KEYWORDS: High Performance Concrete; Temperature; Fiber Reinforcement; Polymer; Mechanical Properties

Citation/Citar como: Xiong, M.-X.; Richard Liew, J.Y. (2015) Spalling behavior and residual resistance of fibre reinforced Ultra-High performance concrete after exposure to high temperatures. Mater. Construcc. 65 [320], e071. http://dx.doi.org/10.3989/mc.2015.00715.

RESUMEN: Comportamiento y resistencias mecánicas residuales de hormigones de ultra altas prestaciones reforzados con fibras tras su exposición a altas temperaturas. En este trabajo se presentan los resultados más relevantes del trabajo experimental realizado para valorar la laminación y las propiedades mecánicas residuales de hormigón de ultra-altas prestaciones tras su exposición a altas temperaturas. La resistencia a la compresión del hormigón de ultra-altas prestaciones osciló entre $160 \mathrm{MPa} 185 \mathrm{MPa}$. El objetivo de este estudio fue descubrir una manera eficaz de prevenir desprendimientos y/o laminaciones en este hormigón y medir sus propiedades mecánicas después de ser sometido al fuego. Las variables estudiadas fueron la presencia y dosificación de fibras, velocidad de calentamiento y condiciones de curado. Los resultados mostraron, tras la exposición a altas temperaturas, que la resistencia a compresión y el módulo de elasticidad del hormigón de ultra-altas prestaciones disminuían más lento que las de un hormigón con resistencia normal. La fibra de polipropileno resultó más eficaz para prevenir desprendimientos que la fibra de acero pero la trabajabilidad se vio afectada. Tras el estudio realizado se recomienda el tipo de fibra más efectiva y la dosis para evitar desprendimientos y garantizar la suficiente capacidad de trabajo para la puesta en obra y bombeo del hormigón de ultra-altas prestaciones.

PALABRAS CLAVE: Hormigón de altas prestaciones; Temperatura; Refuerzo de fibra; Polímeros; Resistencias mecánicas

Copyright: (C) 2015 CSIC. This is an open-access article distributed under the terms of the Creative Commons Attribution-Non Commercial (by-nc) Spain 3.0 License. 


\section{INTRODUCTION}

With the development of concrete technology and the availability of variety of materials such as silica fume and high-range water-reducing admixtures, the production of ultra-high performance concrete (UHPC) with compressive strength higher than $160 \mathrm{MPa}$ is possible nowadays. However, the UHPC has been limited to special applications such as offshore and marine structures, industrial floors, pavements, and security barriers, etc. It has not been used in building structures due to concerns on the brittleness and the spalling behavior under fire. These concerns lead to the situations that the current state-of-the art design codes allow the use of concrete only up to C90/105 for concrete structures and C50/C60 for composite structures (1-4).

It is well known that high strength concrete (HSC) is prone to spall under high temperatures. The spalling is caused by the thermal stress due to the temperature gradient during heating, and by the splitting force owing to the release of vapor around $100{ }^{\circ} \mathrm{C}(5,6)$. It is reported that steel fiber or polymer fiber is effective to prevent spalling of the HSC under high temperatures (7-10). The steel fibers increase the tensile strength and thus resist the thermal stress. The polymer fibers melt after the temperature inside concrete reaches approximately $170{ }^{\circ} \mathrm{C}$. Therefore the built-up vapor pressure is released through the channels left by the melted polymer fibers. The effect of fibers on spalling has not been reported for the UHPC. Since the UHPC is more likely to spall than the HSC, it is necessary to investigate the spalling behavior and provide recommendations for preventing such spalling.

Residual mechanical properties (compressive strength and elastic modulus) are generally measured after the concrete specimen cools down to room temperature. There are three types of residual properties: unstressed without pre-load, heatedstressed, stressed-heated (11). The unstressed residual properties are mostly investigated in literature, which are affected by strength, aggregate type, heating rate, cooling rate, cylinder size, etc. Generally, the compressive strength and elastic modulus of HSC are reduced faster than those of normal strength concrete (NSC) after exposed to high temperatures $(12,13)$. However, there is little information on the residual resistance of UHPC in literature; the test results presented in this paper are expected to fill the research gap.

The present study targets to study the spalling behavior of the UHPC when it is exposed to high temperatures up to $800^{\circ} \mathrm{C}$. An effective way for preventing such spalling, meanwhile maintaining the workability, is to be discovered. In pursuit of better assessment on the residual resistance of structural members made from the fiber reinforced UHPC impaired by fire, the mechanical properties such as compressive strength and elastic modulus are to be provided after it is subjected to temperatures of up to $800{ }^{\circ} \mathrm{C}$ using various heating rates, fiber dosages, and curing conditions.

\section{BASIC MATERIALS}

The basic materials used in this study to produce UHPC were water and Ducorit ${ }^{\mathbb{B}} \mathrm{D} 4$. Ducorit ${ }^{\mathbb{B}} \mathrm{D} 4$ is one of the commercial Ducorit ${ }^{\circledR}$ products (see http:// www.densit.com/). It is made from cementitious mineral powder, superplasticizer and fine bauxite aggregates with maximum sizes less than $4.75 \mathrm{~mm}$ and $49 \%$ less than $0.6 \mathrm{~mm}$. The mixing proportions for the UHPC are shown in Table 1 (14). Workability of the fresh UHPC was tested using the slump flow test in accordance with ASTM C1611/C1611 M-09b. The slump flow spread was $735 \mathrm{~mm}$ (15).

\section{EFFECTS OF FIBER TYPES ON PREVENTION OF SPALLING}

\subsection{Experimental program}

Steel and polypropylene (PP) fibers were used in present study. The properties of steel and polypropylene fibers are given in Table 2. Four batches of UHPC mixtures were prepared as follows:

UHPC: Plain concrete without fibers, the room temperature compressive strength was 166.6 $\mathrm{MPa}$; and

UHPC-S: Plain concrete with $1.0 \%$ steel fibers in terms of volume, the room temperature compressive strength was $170.1 \mathrm{MPa}$; and

UHPC-P: Plain concrete with $1.0 \%$ PP fibers in terms of volume, the room temperature compressive strength was $144.1 \mathrm{MPa}$; and

UHPC-SP: Plain concrete with $0.5 \%$ steel fibers and $0.5 \%$ PP fibers in terms of volume, the room temperature compressive strength was $155.8 \mathrm{MPa}$.

Three cylindrical specimens with a diameter of $100 \mathrm{~mm}$ and height of $200 \mathrm{~mm}$ were cast for each batch. The specimens were cured in lab air for 28 days with plastic sheet covered. The relative humidity of lab air was approximately $85 \%$ and the room temperature was around $30{ }^{\circ} \mathrm{C}$ at daytime and $25^{\circ} \mathrm{C}$ at night. After curing, the specimens were firstly heated up in an electrical oven to a target temperature of

TABLE 1. Mixing proportions of plain UHPC

\begin{tabular}{lccc}
\hline Water/D4 & Water (kg) & D4 (kg) & UHPC Volume (liters) \\
\hline 0.076 & 1.9 & 25 & 9.4 \\
\hline
\end{tabular}


TABLE 2. Properties of steel fiber and polypropylene fiber

\begin{tabular}{lccccc}
\hline Fiber & Code/Type & Diameter $(\mathbf{m m})$ & Length $(\mathbf{m m})$ & Density $\mathbf{( k g / \mathbf { m } ^ { 3 } )}$ & Tensile Strength $(\mathbf{M P a})$ \\
\hline Steel & SF13/80 & 0.16 & 13 & 7850 & 2300 \\
Polypropylene & Monofilament & $0.03 \pm 0.005$ & 13 & $910 \pm 0.01 \%$ & $\geq 450$ \\
\hline
\end{tabular}

$800{ }^{\circ} \mathrm{C}$ with a heating rate of $5^{\circ} \mathrm{C} / \mathrm{min}$. Then, the target temperature was maintained for 4 hours to reach a uniform temperature distribution inside the specimen. After that, the specimen was kept in oven and cooled down naturally to room temperature. During the process of heating and cooling, the specimen was laterally covered by a steel casing with drilled holes for heat flow.

\subsection{Discussions on test results}

There was no spalling observed for specimens of UHPC with PP fibers (UHPC-P, UHPC-SP). However, the specimens of UHPC with steel fibers (UHPC-S) spalled when the temperature inside oven was approximately $490{ }^{\circ} \mathrm{C}$. The spalled specimens are shown in Figure 1. Although the UHPC specimens with steel fibers spalled, there was little debris blown away laterally. The peripheral concrete was peeled off, but still attached to the core concrete by the steel fibers. The electrical oven was damaged by debris from the top of specimen as shown in Figure 1. Following the UHPC-S specimen, the UHPC specimen without fibers was heated where the top of steel casing was welded with additional steel plate. The thickness of the steel plate was $1.5 \mathrm{~mm}$. The plain UHPC specimen also spalled and the spalling debris bent the top cover plate and pushed the steel casing to further damage the oven, as shown in Figure 2. It can be seen that the peripheral concrete was peeled off and broken into pieces, this was different with the steel fiber reinforced specimen. Due to the spalling hazard, the other UHPC-S and the plain UHPC specimens were not heated in case the spalling would further damage the oven. Thus their residual compressive strengths after heating to $800{ }^{\circ} \mathrm{C}$ were not measured.

The residual compressive strengths were tested for all the unspalled specimens after cooling down. The residual compressive strengths and their reduction factors which are the ratios between the residual compressive strengths and their counterparts at room temperature are shown in Table 3 . As mentioned above, the steel fiber slightly increased the room temperature strength, owing to the confinement effect of the steel fibers which increased the radial and circumferential strengths of the cylindrical specimen. The UHPC with $1.0 \%$ of PP fibers or a combination of $0.5 \%$ steel fibers and $0.5 \% \mathrm{PP}$ fibers exhibited lower strengths than that of UHPC without fibers. This was attributed to the effect of PP fibers on workability, resulting in poorer consolidation of the concrete. The difference in residual compressive strengths of UHPC-P and UHPC-SP was approximately $7.5 \%$. Their reduction factors showed the same difference.

The test results indicated that the incorporation of steel fibers was not effective to prevent spalling for the UHPC even with dosage of $1.0 \%$ by volume.
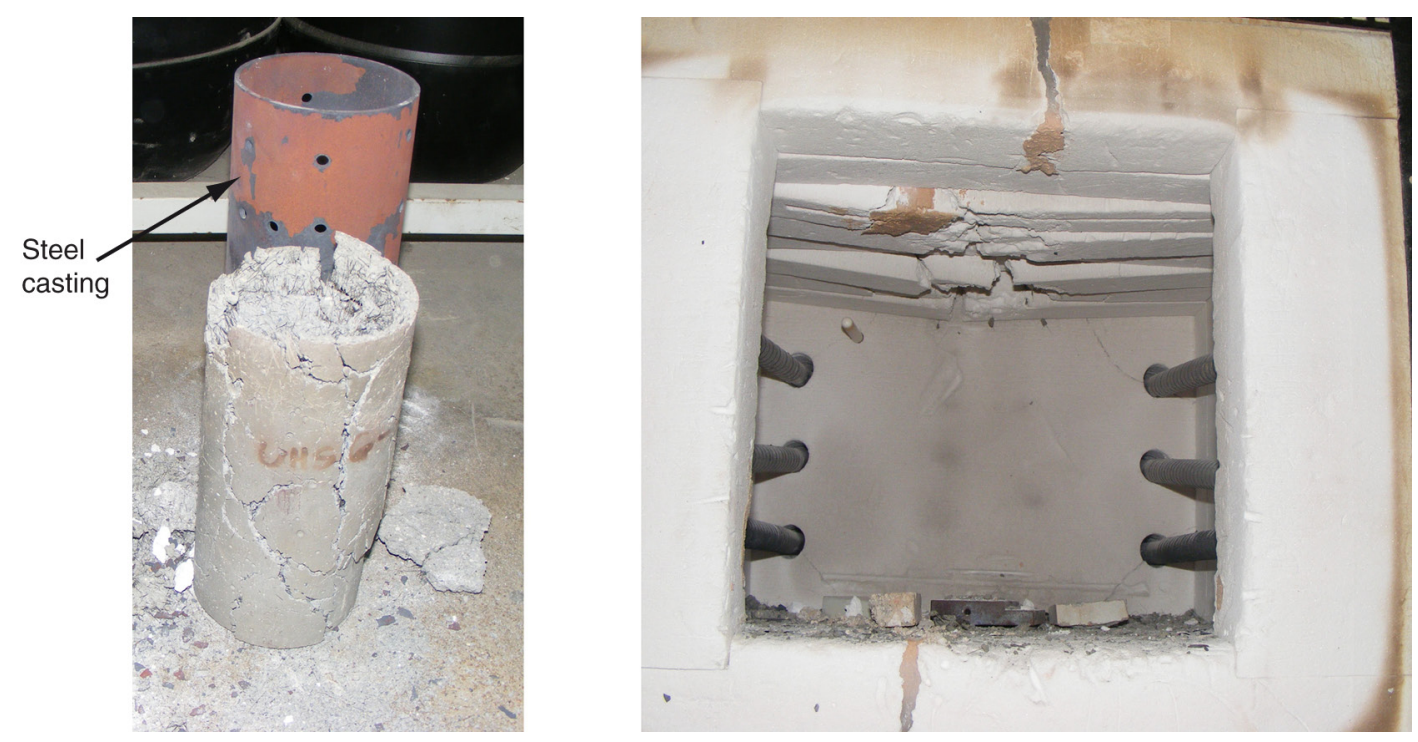

FIGURE 1. Spalled UHPC specimens with steel fibers. 


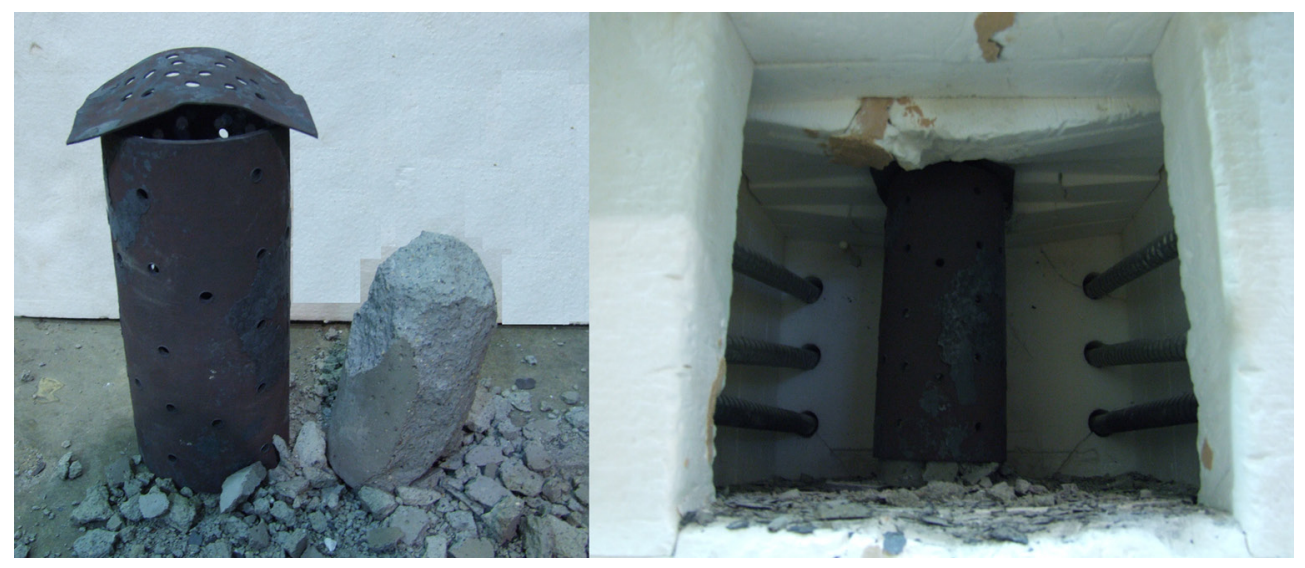

FIGURE 2. Spalled UHPC specimens without fibers.

TABLE 3. The residual compressive strength of UHPC mixtures after $800{ }^{\circ} \mathrm{C}$

\begin{tabular}{lclc}
\hline & \multicolumn{2}{c}{ Strengths (MPa) } & \\
\cline { 2 - 3 } Specimen & Room temperature & \multicolumn{1}{c}{ After $\mathbf{8 0 0}{ }^{\circ} \mathbf{C}$} & Reduction factor \\
\hline UHPC & 166.6 & Spalling (not heated to $800{ }^{\circ} \mathrm{C}$ ) & - \\
UHPC-S & 170.1 & Spalling (no strength was tested) & - \\
UHPC-P & 144.1 & 33.8 & 0.235 \\
UHPC-SP & 155.8 & 39.8 & 0.255 \\
\hline
\end{tabular}

The addition of $1.0 \%$ PP fibers was effective. However, the PP fibers affected the strength of the UHPC specimens due to poor workability caused. As recommended in EN 1992-1-2, more than $2 \mathrm{~kg} / \mathrm{m}^{3}(0.25 \%$ by volume) of monofilament propylene fiber should be included in high strength concrete mixtures to prevent spalling. Hence, $1.0 \%$ PP fibers could be too high to achieve good workability. It is necessary to further reduce the PP fiber dosage.

\section{EFFECT OF POLYPROPYLENE FIBERS ON PREVENTION OF SPALLING}

\subsection{Experimental program}

UHPC mixtures with PP fibers and NSC C50 were investigated. The PP fiber dosages were 0 , $0.1 \%, 0.25 \%$ and $0.5 \%$ in terms of volume. Two heating rates were considered: $5^{\circ} \mathrm{C} / \mathrm{min}$ and $30^{\circ} \mathrm{C} / \mathrm{min}$. NSC C50 was prepared from ordinary Portland cement, sand, coarse aggregates with maximum size $10 \mathrm{~mm}$, and water. The mixing proportions of C50 are shown in Table 4. There was no PP fibers added

TABLE 4. The mixing proportions of NSC C50

\begin{tabular}{lcccc}
\hline Water/Cement & $\begin{array}{c}\text { Water } \\
\left(\mathbf{k g} / \mathbf{m}^{3}\right)\end{array}$ & $\begin{array}{c}\text { Cement } \\
\left(\mathbf{k g} / \mathrm{m}^{3}\right)\end{array}$ & $\begin{array}{c}\text { Sand } \\
\left(\mathbf{k g} / \mathbf{m}^{3}\right)\end{array}$ & $\begin{array}{c}\text { Coarse Aggregate } \\
\left(\mathbf{k g} / \mathbf{m}^{3}\right)\end{array}$ \\
\hline 0.5 & 225 & 450 & 625 & 1005 \\
\hline
\end{tabular}

into the C50. The specimens were also $100 \times 200 \mathrm{~mm}$ cylinders. They were covered by plastic sheet and cured in lab air for 28 days. The target temperatures included room temperature $\left(30^{\circ} \mathrm{C}\right), 200{ }^{\circ} \mathrm{C}, 400{ }^{\circ} \mathrm{C}$, $600{ }^{\circ} \mathrm{C}$ and $800{ }^{\circ} \mathrm{C}$. The heating and cooling processes were the same as mentioned in Section 3.1.

\subsection{Test observations}

No spalling was observed for any specimens with the PP fibers. This indicates that $0.1 \% \mathrm{PP}$ fibers is effective to prevent spalling of the UHPC specimens under high temperature up to $800{ }^{\circ} \mathrm{C}$. The UHPC specimens without PP fibers were not heated after $400{ }^{\circ} \mathrm{C}$ in case the spalled debris would damage the electrical oven. After heating, standard compression tests were carried out to evaluate the residual compressive strength and residual elastic modulus after the UHPC specimens were naturally cooled down to room temperature. The failure modes of the UHPC specimens subjected to various temperatures and compression are shown in Figure 3.

It was observed that the unheated UHPC specimen was crushed into pieces very noisily. However, it exhibited better ductility and lower noise after exposure to the high temperatures. The appearances of the UHPC specimens were different after heated to different target temperatures due to the changes of microstructures. 


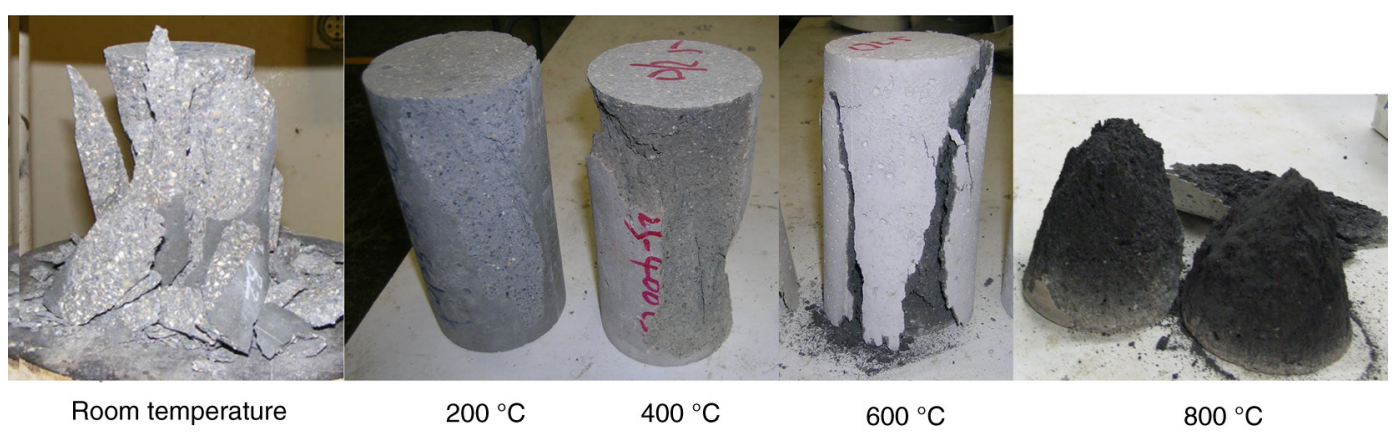

FIGURE 3. Failure modes after subjected to target temperatures and compression.

\subsection{Residual compressive strength}

The residual compressive strengths of the UHPC mixtures and NSC C50 are shown in Table 5. Due to running out of the pre-blended mixture, the batch of UHPC with $0.1 \%$ PP fibers under heating rate of $30{ }^{\circ} \mathrm{C} / \mathrm{min}$ was cast using the pre-blended mixture from second shipment. Table 5 shows that the room temperature strength from the second shipment was higher than those from the first shipment. In general, the residual compressive strength decreased as the dosage of PP fibers increased for the same testing temperature and heating rate, due to the reduced workability.

Compared with the room temperature strength, the residual compressive strength of UHPC slightly increased for temperature at $200{ }^{\circ} \mathrm{C}$, but decreased beyond $200{ }^{\circ} \mathrm{C}$. The reason for the increase of strength at $200{ }^{\circ} \mathrm{C}$ is unclear. There are some hypotheses in the literature (16-18). The prevailing hypothesis is that the increase of strength is attributed to the increase in the forces between the gel particles (Van der Walls forces) due to the water removal and the consequent shrinkage $(19,20)$. The decrease of strength at $400{ }^{\circ} \mathrm{C}, 600{ }^{\circ} \mathrm{C}$, and $800{ }^{\circ} \mathrm{C}$ were related with the decomposition of hydration products such as calcium silicate hydrate (C-S-H) and calcium hydroxide $\mathrm{Ca}(\mathrm{OH})_{2}$, deterioration of aggregates, and cracking due to thermal incompatibility between the aggregate and cement paste which led to stress concentration.
The residual factor in this paper is defined as the ratio of the compressive strength or elastic modulus after heating divided by its counterpart at room temperature. The residual compressive strength factors of UHPC were larger than those of C50 as shown in Figure 4. This is due to the fact that the bauxite aggregate in UHPC exhibited better fire resistance than the conventional siliceous aggregate used for C50. There was no increase of strength at $200{ }^{\circ} \mathrm{C}$ for $\mathrm{C} 50$. This could be related with the water removal which induces shrinkage of concrete while making the microstructure of concrete more porous. Thus, there is a trade-off between the shrinkage and the porosity. The shrinkage increases the Van der Walls forces between gel particles and thus the compressive strength of concrete. However the increase of porosity reduces the strength of concrete. NSC C50 has higher water content than the UHPC. Hence the loss of strength by the increase of porosity overwhelms the increase of strength by shrinkage. As a result, the compressive strength of NSC C50 did not increase at $200^{\circ} \mathrm{C}$.

The effects of PP fiber dosage on the residual compressive strengths of UHPC mixtures are shown in Figure 5 and Figure 6. At the heating rate of $5{ }^{\circ} \mathrm{C} / \mathrm{min}$, the residual compressive strength factors of UHPC with $0.25 \%$ and $0.5 \%$ PP fiber at $400{ }^{\circ} \mathrm{C}$ and $600{ }^{\circ} \mathrm{C}$ were lower than those of UHSC with $0.1 \%$ PP fiber with a difference of approximately $18 \%$. For the other temperatures, they were very similar.

TABLE 5. Residual compressive strengths based on fiber dosage and heating rate (MPa)

\begin{tabular}{|c|c|c|c|c|c|c|c|c|}
\hline \multirow[b]{2}{*}{ Temp. $\left({ }^{\circ} \mathrm{C}\right)$} & \multirow{2}{*}{$\begin{array}{c}\text { UHPC } \\
\text { without fiber } \\
5^{\circ} \mathrm{C} / \mathrm{min}\end{array}$} & \multirow{2}{*}{$\begin{array}{l}\text { C50 without } \\
\text { fiber } \\
5^{\circ} \mathrm{C} / \mathrm{min}\end{array}$} & \multicolumn{2}{|c|}{$\begin{array}{l}\text { UHPC with } \\
0.1 \% \text { fiber }\end{array}$} & \multicolumn{2}{|c|}{$\begin{array}{l}\text { UHPC with } \\
0.25 \% \text { fiber }\end{array}$} & \multicolumn{2}{|c|}{$\begin{array}{l}\text { UHPC with } \\
0.5 \% \text { fiber }\end{array}$} \\
\hline & & & $5^{\circ} \mathrm{C} / \mathrm{min}$ & $30^{\circ} \mathrm{C} / \mathrm{min}$ & $5^{\circ} \mathrm{C} / \mathrm{min}$ & $30^{\circ} \mathrm{C} / \mathrm{min}$ & $5^{\circ} \mathrm{C} / \mathrm{min}$ & $30^{\circ} \mathrm{C} / \mathrm{min}$ \\
\hline 30 & 163 & 46 & 161 & 183 & 151 & 151 & 147 & 147 \\
\hline 200 & 171 & 44 & 171 & 184 & 164 & 159 & 153 & 149 \\
\hline 400 & 128 & 35 & 126 & 128 & 101 & 105 & 97 & 95 \\
\hline 600 & - & 19 & 74 & 80 & 59 & 60 & 52 & 55 \\
\hline 800 & - & 9 & 41 & 28 & 36 & 31 & 34 & 31 \\
\hline
\end{tabular}




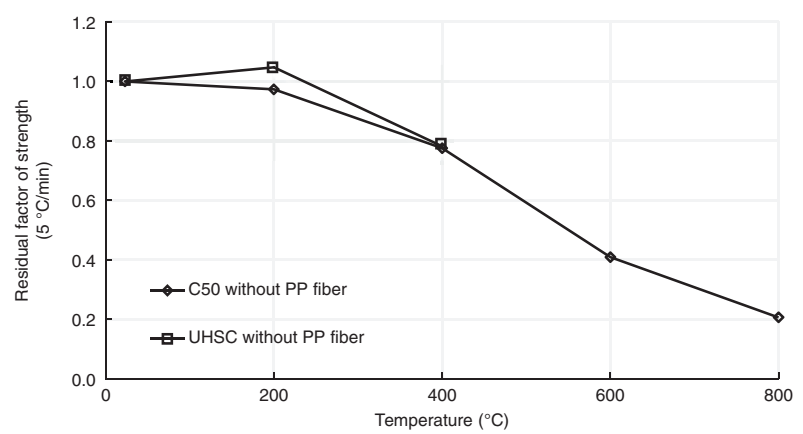

FIgURE 4. Residual compressive strength of UHPC and C50 without PP fiber

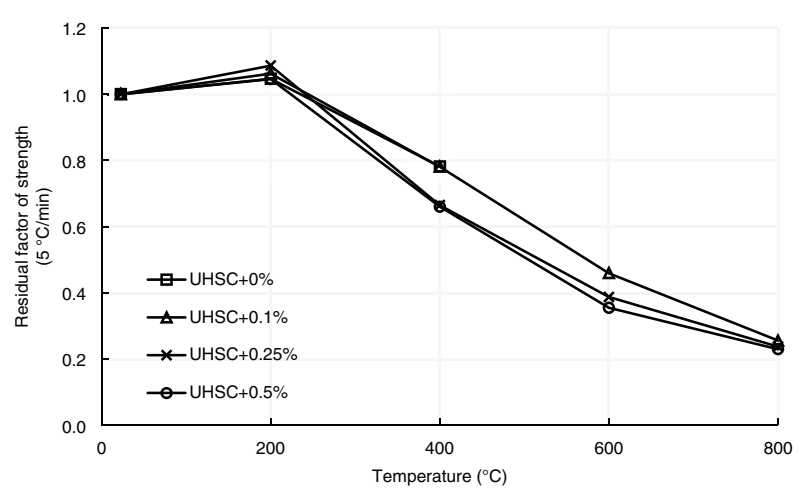

FIgURE 5. Residual compressive strength of UHPC at heating rate of $5^{\circ} \mathrm{C} / \mathrm{min}$.

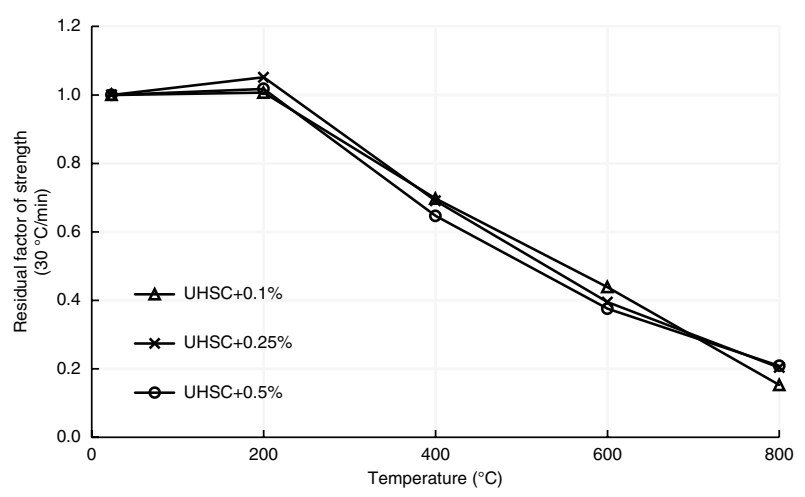

FIGURE 6. Residual compressive strength of UHPC at heating rate of $30^{\circ} \mathrm{C} / \mathrm{min}$.

At the heating rate of $30^{\circ} \mathrm{C} / \mathrm{min}$, the differences were not significant and the compressive strengths were similar. It could be concluded that the compressive strength was reduced slightly faster as PP fiber dosage increased at heating rate of $5^{\circ} \mathrm{C} / \mathrm{min}$, but similar at $30^{\circ} \mathrm{C} / \mathrm{min}$.

The effects of heating rate on the residual compressive strength are shown in Figure 7, Figure 8 and Figure 9. The maximum difference between the

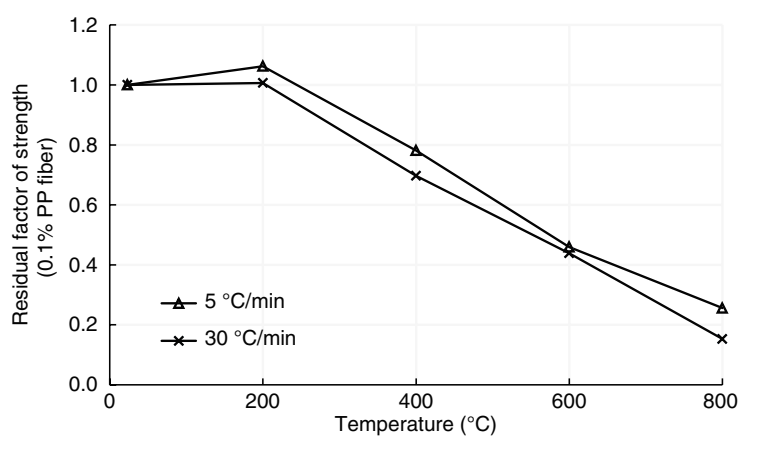

FIgURE 7. Residual compressive strength of UHPC with $0.1 \%$ PP fibers.

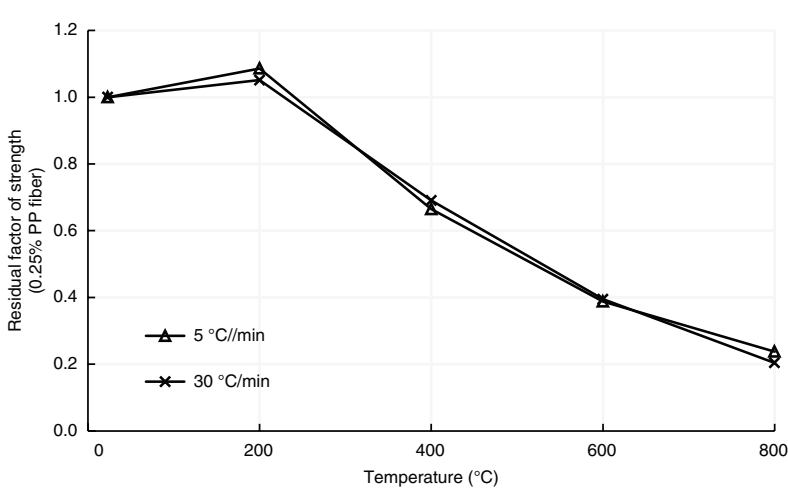

Figure 8. Residual compressive strength of UHPC $0.25 \%$ PP fibers.

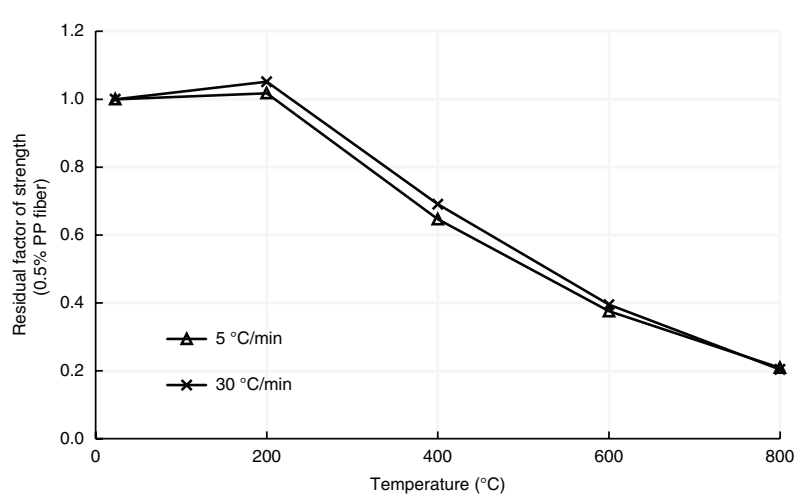

FIGURE 9. Residual compressive strength of UHPC $0.5 \%$ PP fibers.

residual factors at $5{ }^{\circ} \mathrm{C} / \mathrm{min}$ and $30{ }^{\circ} \mathrm{C} / \mathrm{min}$ were $40.3 \%, 14.3 \%$ and $9.2 \%$ as the PP fiber dosage increased from $0.1 \%$ to $0.5 \%$. The trend showed that the compressive strength of UHPC with $0.1 \%$ PP fibers at $30{ }^{\circ} \mathrm{C} / \mathrm{min}$ was reduced faster than that at $5{ }^{\circ} \mathrm{C} / \mathrm{min}$. However as the PP fiber dosage increased, the difference at different heating rates regarding the deterioration of strength was not significant. 
TABLE 6. Residual elastic modulus (GPa) based on fiber dosage and heating rate

\begin{tabular}{|c|c|c|c|c|c|c|c|c|}
\hline \multirow[b]{2}{*}{ Temp. $\left({ }^{\circ} \mathrm{C}\right)$} & \multirow{2}{*}{$\begin{array}{c}\begin{array}{c}\text { UHPC } \\
\text { without fiber }\end{array} \\
5^{\circ} \mathrm{C} / \mathrm{min}\end{array}$} & \multirow{2}{*}{$\begin{array}{c}\begin{array}{c}\mathrm{C50} \text { without } \\
\text { fiber }\end{array} \\
5^{\circ} \mathrm{C} / \mathrm{min}\end{array}$} & \multicolumn{2}{|c|}{ UHPC with $0.1 \%$ fiber } & \multicolumn{2}{|c|}{ UHPC with $0.25 \%$ fiber } & \multicolumn{2}{|c|}{ UHPC with $0.5 \%$ fiber } \\
\hline & & & $5^{\circ} \mathrm{C} / \mathrm{min}$ & $30{ }^{\circ} \mathrm{C} / \mathrm{min}$ & $5^{\circ} \mathrm{C} / \mathrm{min}$ & $30^{\circ} \mathrm{C} / \mathrm{min}$ & $5^{\circ} \mathrm{C} / \mathrm{min}$ & $30^{\circ} \mathrm{C} / \mathrm{min}$ \\
\hline 30 & 60 & 27 & 61 & 65 & 54 & 54 & 53 & 53 \\
\hline 200 & 58 & 22 & 56 & 61 & 51 & 47 & 52 & 43 \\
\hline 400 & 32 & 10 & 28 & 30 & 24 & 22 & 24 & 20 \\
\hline 600 & - & 3 & 22 & 17 & 18 & 15 & 18 & 12 \\
\hline 800 & - & 1 & 21 & 9 & 20 & 12 & 19 & 10 \\
\hline
\end{tabular}

\subsection{Residual elastic modulus}

According to ASTM C469-02 (21), the elastic modulus is the secant modulus between the stress equal to $40 \%$ of peak stress and the stress corresponding to strain of $5 \times 10^{-5}$. Generally, the residual elastic modulus decreased with increasing temperature as given in Table 6, there was no increase at $200{ }^{\circ} \mathrm{C}$. This indicates that the shrinkage of UHPC after water removal has minor effect on the elastic modulus since the primary factors affecting the elastic modulus are the type of aggregate and the presence of sustained stress during heating (22). Comparing the UHPC with the NSC C50 both without addition of PP fibers as shown in Figure 10, the residual modulus factors of C50 were smaller than those of UHPC at $200{ }^{\circ} \mathrm{C}$ and $400{ }^{\circ} \mathrm{C}$. The difference was approximately $13 \%$ and $35 \%$, respectively. Similarly, this was attributed to the type of aggregate.

The effects of PP fiber dosage on the residual modulus factors of UHPC mixtures are shown in Figure 11 and Figure 12. At heat rate of $5{ }^{\circ} \mathrm{C} / \mathrm{min}$, no clear difference was observed with regard to the effect of PP fiber dosage. However at heating rate of $30{ }^{\circ} \mathrm{C} / \mathrm{min}$, the elastic modulus was reduced faster with the increase of the dosage of PP fiber.

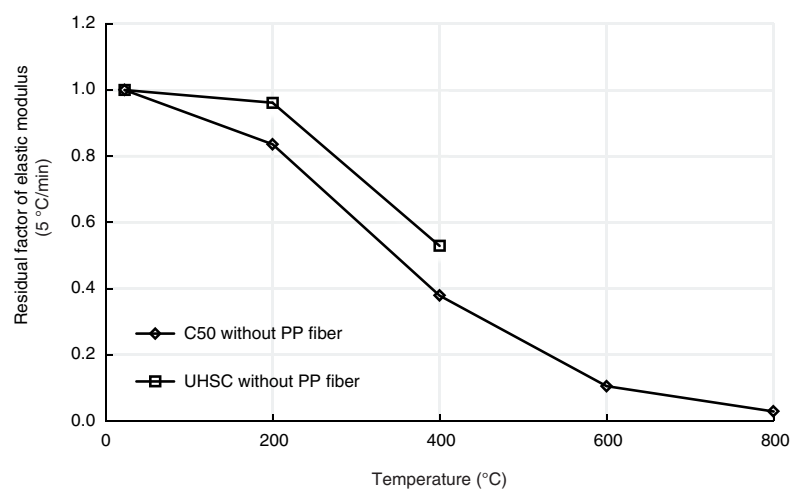

FIgURE 10. Residual elastic modulusi for UHPC and C50 without PP fiber.
The effects of heating rate on the residual modulus factors are shown in Figures 13-15. For PP fiber dosage of $0.1 \%$, the difference between the residual factors at $5{ }^{\circ} \mathrm{C} / \mathrm{min}$ and $30{ }^{\circ} \mathrm{C} / \mathrm{min}$ was minimal up to $400{ }^{\circ} \mathrm{C}$. As the PP fiber dosage increased, the said difference became significant. The difference at $600^{\circ} \mathrm{C}$ and $800{ }^{\circ} \mathrm{C}$ was significant, irrespective of fiber dosage. It could be concluded that the elastic modulus was reduced faster at higher heating rate. The difference between the residual factors of $5{ }^{\circ} \mathrm{C} / \mathrm{min}$ and $30^{\circ} \mathrm{C} / \mathrm{min}$ increased as the PP fiber dosage increased.

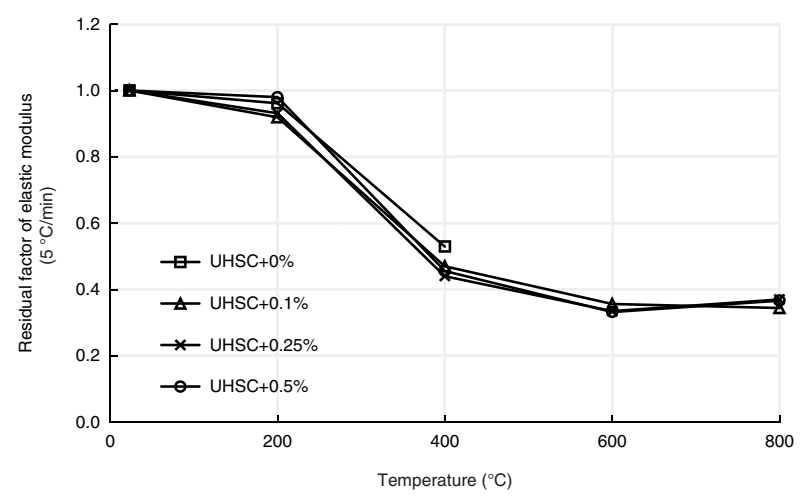

FIGURE 11. Residual elastic modulus for UHPC at heating rate of $5{ }^{\circ} \mathrm{C} / \mathrm{min}$.

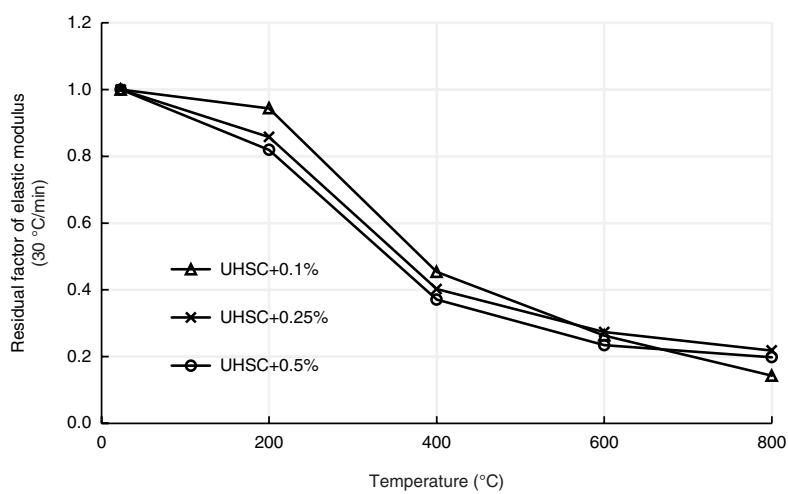

FIGURE 12. Residual elastic modulus for UHPC at heating rate of $30^{\circ} \mathrm{C} / \mathrm{min}$. 


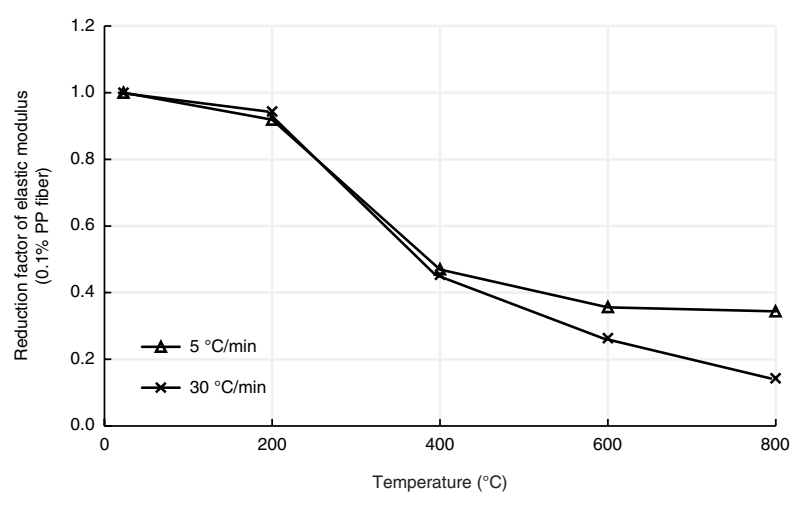

FIGURE 13. Residual elastic modulus for UHPC with $0.1 \%$ PP fibers.

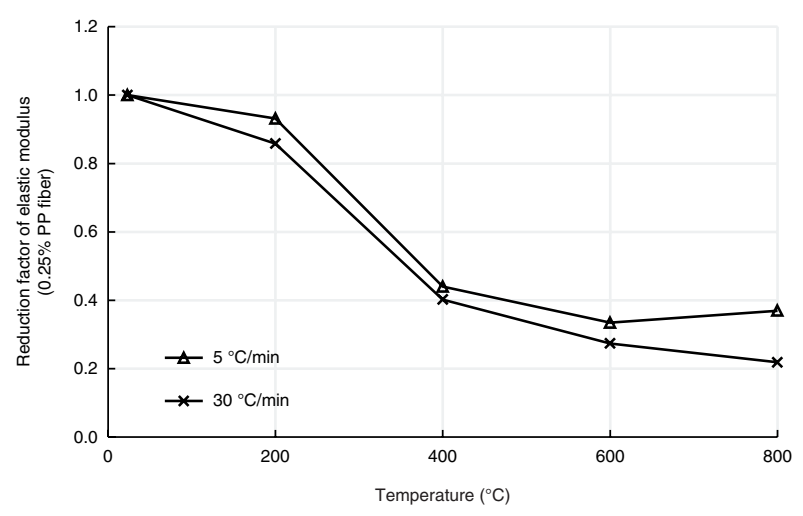

Figure 14. Residual elastic modulus for UHPC with $0.25 \%$ PP fibers.

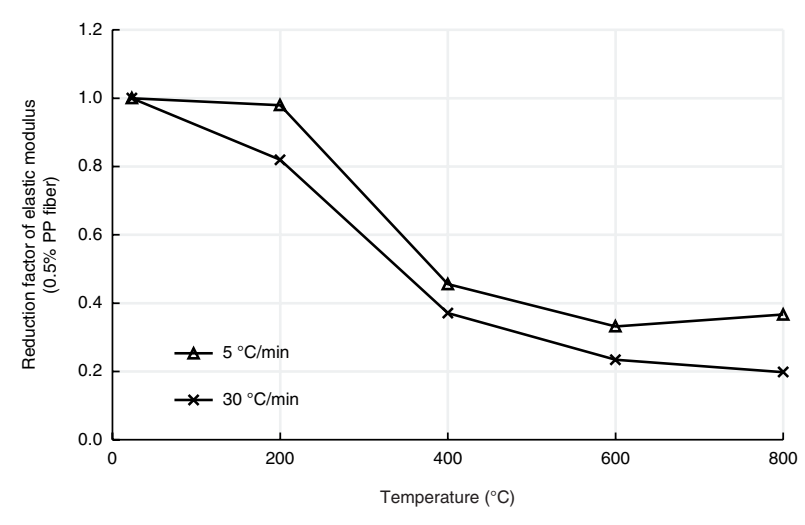

FIGURE 15. Residual elastic modulus for UHPC with $0.5 \%$ PP fibers.

\section{EFFECT OF CURING CONDITION}

\subsection{Experimental program}

UHPC with $0.1 \%$ PP fibers by volume was investigated. The UHPC was made by using the pre-blended mixture from the second shipment as mentioned above. The cylindrical specimens $(100 \times 200 \mathrm{~mm})$ were cured in three conditions as follows:
UHPC-D: Bare specimens were cured in open lab air with a relative humidity $(\mathrm{RH})$ of $85 \%$ and temperature of $30{ }^{\circ} \mathrm{C}$ for daytime and $25^{\circ} \mathrm{C}$ for night; and

UHPC-H: Bare specimens were cured in fog room with a constant RH of $100 \%$ and temperature of $28^{\circ} \mathrm{C}$; and

UHPC-S: Specimens were sealed with aluminum foil and cured in lab air. The specimens were prepared to reflect the curing condition where UHPC is encased in hollow steel tubes.

Three cylinders were prepared for each batch. After 28 days curing, the specimens were heated. The heating rate was $30{ }^{\circ} \mathrm{C} / \mathrm{min}$. The heating, cooling, and testing procedures were the same with those aforementioned.

\subsection{Discussions on test results}

There was no spalling observed during heating for all specimens due to the addition of $0.1 \%$ PP fibers. The residual compressive strength and modulus are shown in Table 7. At room temperature, the strength and modulus of UHPC mixtures were not significantly affected by the curing conditions. This might be due to the fact that UHPC is very dense and the permeability is low. Thus, little water was absorbed even cured in fog room for 28 days. Regarding the site inspection during building construction, the test results implicitly indicated that the mechanical properties of UHPC cured in the open environment can be used for the one encased in hollow steel tubular columns. This facilitates site inspection since it is difficult to take out UHPC specimens from the composite columns for static tests.

The residual factors of compressive strength and elastic modulus with various curing conditions are plotted in Figure 16 and Figure 17. No clear difference was observed with regard to the effects of curing conditions. This is because the residual compressive strength and elastic modulus were measured after the water was removed by heating. Thus the residual properties would be similar regardless of how much water have been absorbed before heating. Comparing the residual factors between the residual compressive strength and the residual elastic modulus as shown in Figure 16 and Figure 17, the residual modulus was reduced faster under all curing conditions. Especially at $400{ }^{\circ} \mathrm{C}$, the residual elastic modulus was reduced by $55 \%$ but $30 \%$ for the residual compressive strength. It indicated that the elastic modulus was more sensitive to fire compared with the compressive strength. Thus, the composite columns filled with the UHPC may be more likely governed by buckling failure rather than cross-sectional failure under fire. 
Spalling behavior and residual resistance of fibre reinforced Ultra-High performance concrete after exposure to high temperatures $\bullet 9$

TABLE 7. Residual compressive strength and residual elastic modulus based on curing conditions

\begin{tabular}{|c|c|c|c|c|c|c|}
\hline \multirow[b]{2}{*}{ Temp. $\left({ }^{\circ} \mathrm{C}\right)$} & \multicolumn{2}{|c|}{ UHPC-D } & \multicolumn{2}{|c|}{ UHPC-H } & \multicolumn{2}{|c|}{ UHPC-S } \\
\hline & $f_{\text {ck }}(\mathrm{MPa})$ & $E_{\mathrm{c}}(\mathrm{GPa})$ & $f_{\text {ck }}(\mathrm{MPa})$ & $E_{\mathrm{c}}(\mathrm{GPa})$ & $f_{\text {ck }}(\mathrm{MPa})$ & $E_{\mathrm{c}}(\mathrm{GPa})$ \\
\hline 30 & 183 & 65 & 181 & 67 & 186 & 66 \\
\hline 200 & 184 & 61 & 186 & 60 & 189 & 60 \\
\hline 400 & 128 & 30 & 137 & 29 & 129 & 30 \\
\hline 600 & 80 & 17 & 74 & 18 & 77 & 18 \\
\hline 800 & 28 & 9 & 31 & 10 & 30 & 9 \\
\hline
\end{tabular}

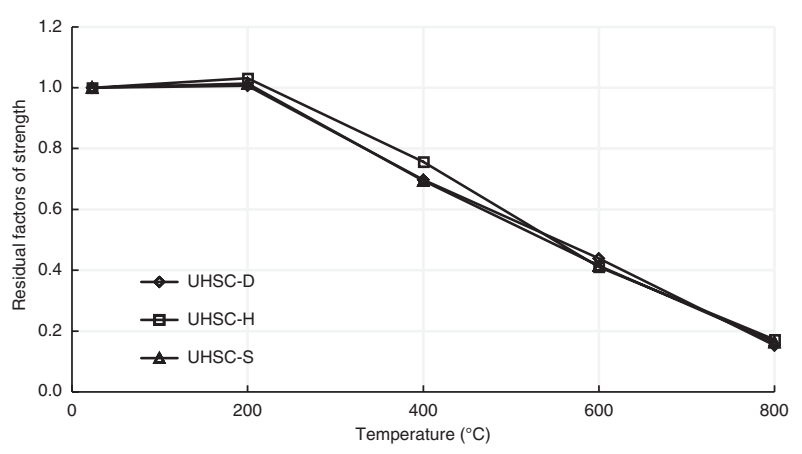

FIGURE 16. Residual factors of strength under all curing conditions.

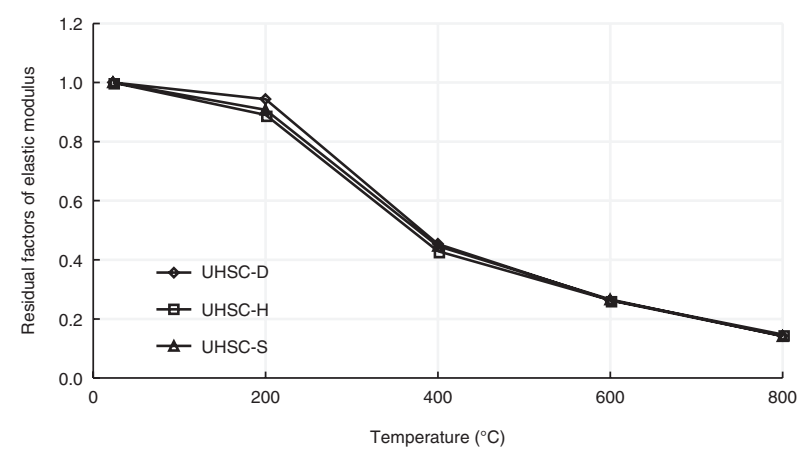

FIGURE 17. Residual factors of elastic modulus under all curing conditions.

\section{CONCLUSIONS}

The spalling behavior and residual resistance of ultra-high performance concrete were introduced in this paper. The effective way has been found to prevent spalling of the ultra-high performance concrete through this research. Fiber dosage, heating rate and curing conditions were investigated for the residual resistance of the ultra-high performance concrete specimens. Some main findings can be obtained as follows.

(1) Steel fiber is not effective to prevent spalling of the ultra-high performance concrete even its dosage is $1.0 \%$ by volume. Polypropylene fiber with dosage of $0.1 \%$ is found to be effective for temperature up to $800{ }^{\circ} \mathrm{C}$ since the polypropylene fibers melt and then leave voids for release of vapor.

(2) Strength of the ultra-high performance concrete at heating rate of $30{ }^{\circ} \mathrm{C} / \mathrm{min}$ is reduced faster than that at $5{ }^{\circ} \mathrm{C} / \mathrm{min}$ when the polypropylene fiber dosage is $0.1 \%$. As the polypropylene fiber dosage increases, the reduction is similar at different heating rates. At $5{ }^{\circ} \mathrm{C} / \mathrm{min}$, strength is reduced faster as the polypropylene fiber dosage increases. At $30^{\circ} \mathrm{C} / \mathrm{min}$, the reduction of strength is similar for various polypropylene fiber dosages.

(3) Elastic modulus of the ultra-high performance concrete is reduced faster at higher heating rate. The difference between residual factors at $5{ }^{\circ} \mathrm{C} / \mathrm{min}$ and $30^{\circ} \mathrm{C} / \mathrm{min}$ increases as the polypropylene fiber dosage increases. The polypropylene fiber dosage does not significantly affect the residual modulus factor at $5{ }^{\circ} \mathrm{C} / \mathrm{min}$, however at heating rate of $30{ }^{\circ} \mathrm{C} / \mathrm{min}$, the elastic modulus is reduced faster with the increase of PP fiber dosage.

(4) There is an increase of strength after exposure to $200^{\circ} \mathrm{C}$, due to the shrinkage by water removal. The increase is not found for elastic modulus.

(5) Strength and elastic modulus of the ultra-high performance concrete are reduced slower after heating than those of $\mathrm{C} 50$, due to the fire resistant bauxite aggregate in the ultra-high strength concrete.

(6) Curing condition exhibits insignificant effects on the residual compressive strength and residual elastic modulus of the ultra-high strength concrete. For all curing conditions, the elastic modulus is generally reduced faster than the strength after heating.

\section{ACKNOWLEDGEMENT}

The authors would like to acknowledge the funding support by Singapore A*STAR for research project "Steel-concrete composite systems employing ultra-high strength steel and concrete for sustainable high-rise construction" under SERC Grant No: 0921420045. 


\section{REFERENCES}

1. EN 1992-1-1. (2004) Eurocode 2: Design of concrete structures - Part 1-1: General rules and rules for buildings, European Committee for Standardization.

2. EN 1992-1-2. (2004) Eurocode 2: Design of concrete structures - Part 1-2: General rules-structural fire design, European Committee for Standardization.

3. EN 1994-1-1. (2004) Eurocode 4: Design of composite steel and concrete structures - Part 1-1: General rules and rules for buildings, European Committee for Standardization.

4. EN 1994-1-2. (2005) Eurocode 4: Design of composite steel and concrete structures - Part 1-2: General rules - Structural fire design, European Committee for Standardization.

5. Ali, F.A.; Connor, D.O.; Tair, A.A. (2001) Explosive spalling of high-strength concrete columns in fire. Mag. Concr. Res. 53 [3], 197-204. http://dx.doi.org/10.1680/macr.2001. 53.3.197.

6. Ko, J.; Ryu, D.; Noguchi, T. (2011) The spalling mechanism of high-strength concrete under fire. Mag. Concr. Res. 63 [5], 357-370. http://dx.doi.org/10.1680/macr.10.00002

7. Chen, B.; Liu, J.Y. (2004) Residual strength of hybrid-fiberreinforced high-strength concrete after exposure to high temperatures. Cem. Concr. Res. 34 [6], 1065-1069. http:// dx.doi.org/10.1016/j.cemconres.2003.11.010.

8. Han, C.C.; Hwang, Y.S.; Yang, S.H.; Gowripalan, N. (2005) Performance of spalling resistance of high performance concrete with polypropylene fiber contents and lateral confinement. Cem. Concr. Res. 35 [9], 1747-1753. http://dx.doi. org/10.1016/j.cemconres.2004.11.013.

9. Zeiml, M.; Leithner, D.; Lackner, R.; Mang, H.A. (2006) How do polypropylene fibers improve the spalling behavior of in-situ concrete? Cem. Concr. Res. 36 [5],929-942. http:// dx.doi.org/10.1016/j.cemconres.2005.12.018.

10. Hadi, M.N.S. (2007) Using fibres to enhance the properties of concrete columns. Constr. Build. Mater. 21 [1], 118-125. http://dx.doi.org/10.1016/j.conbuildmat.2005.06.028.

11. RILEM Technical Committee. (2007) Recommendation of RILEM TC 200-HTC: mechanical concrete properties at high temperatures - modeling and applications, Part 2: stress-strain relation. Mater. Struct. 40 [9], 855-864. http:// dx.doi.org/10.1617/s11527-007-9286-1.

12. Morita, T.; Saito, H.; Kumagai, H. (1992) Residual mechanical properties of high strength concrete members exposed to high temperature - Part 1: Test on material properties. Summaries of Technical Papers of Annual Meeting, Architectural Institute of Japan, Niigata.

13. Felicetti, R.; Gambarova, P.G.; Rosati, G.P.; Corsi, F.; Giannuzzi, G. (1996) Residual mechanical properties of high strength concretes subjected to high temperature cycles. Proceedings of 4 th International Symposium on Utilization of High Strength/High Performance Concrete, Paris France, 579-588.

14. Liew, J.Y.R.; Xiong, D.X. (2012) Ultra-high strength concrete filled composite columns for multi-storey building construction. Adv. Struct. Eng. 15 [9], 1487-1503. http:// dx.doi.org/10.1260/1369-4332.15.9.1487.

15. Xiong, D.X. (2012) Structural behaviour of concrete filled steel tubes with high strength materials. $\mathrm{PhD}$ thesis, National University of Singapore.

16. Dias, W.P.S.; Khoury, G.A.; Sullivan, P.J.E. (1990) Mechanical properties of hardened cement paste exposed to temperatures up to $700{ }^{\circ} \mathrm{C}$. ACI Mater. J. 87 [2], 160-166. http://dx.doi. org/10.14359/1981.

17. Khoury, G.A. (1992) Compressive strength of concrete at high temperature: a reassessment. Mag. Concr. Res. 44 [161], 291-309. http://dx.doi.org/10.1680/macr.1992.44.161.291.

18. Tanyildizi, H.; Coskun, A. (2008) The effect of high temperature on compressive strength and splitting tensile strength of structural lightweight concrete containing fly ash. Constr. Build. Mater. 22 [11], 2269-2275. http://dx.doi.org/10.1016/j. conbuildmat.2007.07.033

19. Castillo, C.; Durrani, A.J. (1990) Effect of transient high temperature on high strength concrete. ACI Mater. J. 87 [1], 47-53. http://dx.doi.org/10.14359/2356.

20. Behnood, A.; Ziari, H. (2008) Effects of silica fume addition and water to cement ratio on the properties of highstrength concrete after exposure to high temperatures. Cem. Concr. Compos. 30 [2], 106-112. http://dx.doi.org/10.1016/j. cemconcomp.2007.06.003.

21. ASTM C 469-02 (2002). Standard test method for static modulus of elasticity and Poisson's ratio of concrete in compression. ASTM International, United States.

22. Naus, D.J. (2006) The effect of elevated temperature on concrete material and structures - a literature review. Oak Ridge National Laboratory, U.S. Nuclear Regulatory Commision, Office of Nuclear Regulatory Research, Washington DC. 